REFLEKSI HUKUM

Jurnal Ilmu Hukum
p-ISSN 2541-4984 | e-ISSN 2541-5417

Volume 4 Nomor 2, April 2020, Halaman 135-154

DOI: https://doi.org/10.24246/jrh.2020.v4.i2.p135-154

Open access at: http:// journal.uksw.edu/refleksihukum Penerbit: Fakultas Hukum Universitas Kristen Satya Wacana

\title{
NORMALISASI HUBUNGAN PUSAT - DAERAH SESUAI KONSTITUSI PRESIDENSIAL
}

\author{
Titon Slamet Kurnia \\ Fakultas Hukum Universitas Kristen Satya Wacana \\ Korespondensi: titonslamet@gmail.com
}

Naskah diterima: 21 Januari 2020|Direvisi: 5 Februari 2020 |Disetujui: 31 Maret 2020

\begin{abstract}
Abstrak
Tulisan ini mengidentifikasi (atau mendiagnosis) bahwa sistem pemerintahan presidensial kita mengalami praktik abnormal, rivalitas politik, dalam hubungan antara presiden dengan pemerintahan daerah, khususnya kepala daerah. Untuk menanggapi isu tersebut, tulisan ini berpendapat bahwa kita perlu melakukan penataan kembali hubungan antara presiden dengan pemerintahan daerah supaya lebih taat asas terhadap preskripsi dari konstitusi presidensial kita. Untuk itu, tulisan ini menggunakan teori unitary executive sebagai alat interpretasi terhadap kekuasaan eksekutif presiden dalam Pasal 4 ayat (1) UUD NRI 1945. Sesuai usulan tersebut maka tulisan ini memberikan preskripsi supaya presiden seharusnya diberikan kekuasaan untuk menunjuk dan memberhentikan kepala daerah, khususnya gubernur (kepala daerah provinsi).

Kata-kata Kunci: Presiden; Pemerintahan Daerah; Presidensialisme.

Abstract

This article identified that our presidential system faced abnormal practice, i.e. political rivalry, in the relationship between the president and the local government, especially head of local government. Responding the issue, this article suggests that we need to re-organize the relationship between the president and the local governmentto be more consistent with the prescription of our presidential constitution. To do so, this article uses unitary executive theory as an interpretive tool over the executive power of the president withinArticle 4.1. UUD NRI 1945. According to this proposal, this article prescribes that the president should be given the power of appointment and removal over the head of local government, in particular the governor (head of provincial government).
\end{abstract}

Keywords: President; Local Government; Presidentialism. 


\section{PENDAHULUAN}

Artikel ini hendak mendiskusikan isu hukum tentang penataan kembali hubungan pusat - daerah di Indonesia sesuai dengan sistem pemerintahan presidensial (presidensialisme) yang merupakan asas dari konstitusi kita, Undang-Undang Dasar Negara Republik Indonesia Tahun 1945 (UUD NRI 1945). Tentang isu tersebut, hubungan pusat daerah, masih terlihat ada kondisi abnormal. Kondisi tersebut adalah "rivalitas" antara presiden dengan kepala daerah. Fenomena kepala daerah yang menunjukkan sikap "penentangan" kepada presiden merupakan implikasi dari kuatnya legitimasi demokratis, walaupun sifatnya lokal, kepala daerah yang dipilih secara langsung oleh rakyat, sehingga kepala daerah tersebut tidak merasa bahwa presiden adalah "bos-nya".

Bentuk konkret dari fenomena tersebut adalah yang belakangan ini kita dengar dengan pelabelan "gubernur rasa presiden" atau "gubernur Indonesia" untuk menunjuk pada figur tertentu dari kepala daerah yang sedang menjabat (yang berusaha "tampil beda" dari presidennya). ${ }^{1}$ Dari sisi demokrasi hal ini bukan masalah, bahkan justru bermakna positif sebagai bentuk kaderisasi calon pemimpin di masa depan untuk memberikan semakin banyak alternatif pemimpin politik.
Tetapi dari sisi asas presidensialisme, hal ini merupakan isu sangat serius (selain soal kepantasan dari aspek hierarki kekuasaan), terlebih fenomena penentangan kepada presiden tersebut sungguh-sungguh dilakukan dengan motivasi untuk mendapatkan limpahan efek elektoral di masa mendatang.

Atas dasar kondisi abnormal seperti dijelaskan di atas, tulisan ini hendak mengusulkan proses constitutional reform dengan fokus normalisasi hubungan pusat-daerah menurut konstitusi presidensial. Fokus usulan ini adalah menghilangkan potensi rivalitas antara presiden dengan kepala daerah (khususnya gubernur) sembari menegaskan bahwa presiden sebagai kepala pemerintahan (Chief Executive) adalah penanggung jawab tunggal semua urusan pemerintahan sehingga seyogianya penyelenggara urusan pemerintahan, khususnya pejabat politik, harus sedapat mungkin di bawah kontrol eksklusif presiden dengan jalan presiden diberikan kekuasaan appointment and removal (menunjuk dan memberhentikan) mereka secara unilateral. Pemikiran tersebut, dalam Teori Konstitusi yang dikembangkan yuris-yuris konstitusional Amerika Serikat yang konstitusinya sama seperti kita - konstitusi presidensial, disebut unitary executive.

Pemberitaan oleh media massa berikut menggambarkan secara tepat isu abnormalitas hubungan pusat - daerah seperti dijelaskan di atas, lepas dari apakah pemberitaan tersebut memberitakan fakta yang sebenarnya ataukah memberitakan sandiwara yang sedang terjadi sebagai fakta untuk diberitakan. Herdanang Ahmad Fauzan, 'Beda Pandangan Anies dengan Jokowi dan Basuki soal Penyebab Banjir' (Tirto, 3 Januari 2020) <https://tirto.id/beda-pandangan-anies-dengan-jokowidan-basuki-soal-penyebab-banjir-eqnp> diakses 21 Januari 2020; Riyan Setiawan, 'Polemik Abadi Anies dan Jokowi: Naturalisasi vs Normalisasi Sungai' (Tirto, 10 Januari 2020) <https://tirto.id/polemik-abadi-anies-jokowi-naturalisasi-vs-normalisasi-sungai-erBs> diakses 21 Januari 2020. 


\section{PEMBAHASAN}

\section{Pasal 4 ayat (1) UUD NRI 1945 dan Keberlakuan Asas Presidensialisme: Presiden sebagai Unitary Executive}

UUD NRI 1945 adalah konstitusi presidensial, yaitu konstitusi yang mendesain hubungan antara legislatif eksekutifnya sesuai asas presidensialisme. Konstitusi presidensial memiliki kriteria:

the executive (that is, the president) and the legislature are elected separately and directly by the voters. The legislature has no primary role in the selection of the president; his tenure in office is fixed; and policy failures, popular discontent with his leadership, or adverse votes against his policy preference in the legislature cannot drive him from office prematurely. He can be forced to leave office before the end of his term only with extraordinary actions. $^{2}$

UUD NRI 1945 layak dikualifikasikan sebagai konstitusi presidensial karena ketentuan Pasal 6A, Pasal 7, Pasal 7A, Pasal 7B dan Pasal 7C UUD NRI 1945 sudah memenuhi kriteria tersebut. Namun demikian, keberlakuan asas presidensialisme tidak hanya berhenti sampai pada pengertian di atas, tetapi juga implikasinya bagi kekuasaan presiden, yaitu kekuasaan pemerintahan.
Atas dasar itu, sub-judul ini akan secara spesifik mendiskusikan makna dari asas presidensialisme terhadap kekuasaan presiden berdasarkan Pasal 4 ayat (1) UUD NRI 1945. Sebagai interpretasi yang dikehendaki oleh asas presidensialisme saya menawarkan interpretasi bahwa presiden, dengan kekuasaannya sesuai Pasal 4 ayat (1) UUD NRI 1945 adalah unitary executive.

Teori unitary executive adalah teori tentang ranah kekuasaan presiden di bidang kekuasaan eksekutif atau pemerintahan, yaitu kekuasaan 'to execute the laws'. ${ }^{3}$ Dalam formula paling sederhana, teori unitary executive adalah: 'the President's sole authority to execute the law.'4 Kekuasaan presiden sendiri untuk melaksanakan undangundang (UU) mencerminkan posisi presiden sebagai kepala pemerintahan atau kepala eksekutif yang tunggal. ${ }^{5}$ Itu artinya, yang tunggal adalah kepalanya, yaitu presiden, sehingga tidak ada kepala selain presiden, yang mengepalai kekuasaan eksekutif.

Dalam praktiknya, presiden tidak sendiri ketika melaksanakan UU karena dibantu oleh pejabat-pejabat di lingkungan kekuasaan eksekutif. Dengan kondisi demikian maka presiden menjadi penanggung jawab akhir dalam semua pelaksanaan UU sebagai ranah

Michael L. Mezey, Presidentialism: Power in Comparative Perspective (Lynne Rienner Publishers 2013) 7.

3 Steven G. Calabresi and Christopher S. Yoo, 'The Unitary Executive During the First-Half Century' (1997) 47 (4) Case Western Reserve Law Review 1451, 1452.

4 Christopher S. Yoo, Steven G. Calabresi and Laurence D. Nee, 'The Unitary Executive During the Third-Half Century, 1889-1945’ (2004) 80 (1) Notre Dame Law Review 1, 108.

$5 \quad$ Mengacu pada Art. II Konstitusi Amerika Serikat Miller menyimpulkan: "The starting point for textual analysis is the basic grant of authority to the President: 't the executive power shall be vested in a President of the United States of America.' The Constitution is crytal clear that the 'executive power' whatever that might be - was to be vested in a single individual." Itu artinya, tanpa penjelasan lebih lanjut, dengan rumusan seperti Art. II Konstitusi Amerika Serikat, unitary executive sudah berlaku secara otomatis sebagai implikasinya. Geoffrey P. Miller, 'Independent Agencies' (1986) (1) The Supreme Court Review 41, 58. 
kekuasaan eksekutif. Menjelaskan logika dari konsepsi unitary executive pada presiden, Saikrishna B. Prakash mengajukan pertanyaan retoris sebagai berikut:

As a unitary executive responsible for the administration of the laws, the President was to have complete authority over all other executive officers. If the President was accountable for the administration of the laws, should he not have the ability to command those who help him administrate those laws?6

Dengan pertanyaan retoris tersebut sesungguhnya jawaban yang dikehendaki oleh penanya sudah eksplisit: Karena presiden "accountable for the administration of the laws" maka seyogianya presiden memiliki "the ability to command those who help him administrate those laws".

$$
\text { Ruang lingkup kekuasaan }
$$
eksekutif pada presiden berdasarkan teori unitary executive pada hakikatnya mencakup tiga aspek:

The president's power to remove subordinate policy-making officials at will, the president's power to direct the manner in which subordinate officials exercise discretionary executive power, and the president's power to veto or nullify such officials' exercises of discretionary executive power. ${ }^{7}$
Pada kesempatan lain, dengan rumusan kalimat agak berbeda tetapi secara substantif masih sama: "Presidential removal power, power to gather information from subordinate executive officials, and power to bind subordinate executive officials." 8

Dengan keberlakuan teori unitary executive sebagai prinsip interpretif terhadap kekuasaan eksekutif pada presiden maka yang ingin dituju adalah lebih terpusatnya kekuasaan eksekutif pada presiden sehingga memudahkan tanggung jawab atas pelaksanaannya. Terdesentralisasinya kekuasaan eksekutif tidak dikehendaki. Menjelaskan dengan background sistem konstitusional Amerika Serikat Harold J. Krent menyatakan:

The idea of a unitary executive is neither new nor radical. The Framers rejected several proposals to split the executive, and there have been adherents of a strong centralized executive ever since, from George Washington to William Howard Taft to Ronald Reagan. ${ }^{9}$

Justifikasinya untuk 'accountability and effective leadership,'10 di mana pada analisis akhir: 'The President stands responsible for all discharge of policy and is judged by his or her performance on election day.' 11

6 Saikrishna B. Prakash, 'Hail to the Chief Administrator: The Framers and the President's Administrative Powers' (1993) 102 (4) Yale Law Journal 991, 1014.

7 Christopher S. Yoo, Steven G. Calabresi and Anthony J. Colangelo, The Unitary Executive in the Modern Era, 1945-2004' (2005) 90 (2) Iowa Law Review 601, 607; Steven G. Calabresi and Christopher S. Yoo, 'The Unitary Executive During the Second-Half Century' (2003) 26 (3) Harvard Journal of Law and Public Policy 667, 668.

8 Steven G. Calabresi and Christopher S. Yoo, 'The Unitary Executive During the First-Half Century' (n 3).

$9 \quad$ Harold J. Krent, 'From a Unitary Executive to a Unilateral Presidency' (2008) 88 (2) Boston University Law Review 523, 525-526.

$10 \quad$ Ibid., 526. Lihat juga Lawrence Lessig and Cass R. Sunstein, 'The President and the Administration' (1994) 94 (1) Columbia Law Review 1, 2.

11 Krent, 'From a Unitary Executive to a Unilateral Presidency' (n 9). 
Sebaliknya, dengan plural executive maka 'responsibility may be shrouded, and the costs of determining where responsibility lies increase.' 12 Unitary executive diperlukan presiden dalam rangka 'to safeguard the ability of Presidents to superintend execution of the law.'13 Kapasitas ini sangat penting karena presiden yang harus bertanggung jawab atas semua pelaksanaan kekuasaan eksekutif.

Teori unitary executive dielaborasi oleh Presiden Thomas Jefferson dengan pra-pemahaman: 'the execution of laws is more important than the making of them.'14 Jefferson mendukung teori unitary executive, termasuk mengkampanyekannya "melawan" teori plural executive yang diterapkan Perancis pasca revolusi. Tahun 1796 Jefferson menulis: 'I fear the oligarchical executive of the French will not do, since a 'small council' necessarily gets into 'cabals and quarrels,' the more bitter and relentless the fewer they are.'15 Jefferson menyarankan supaya Perancis belajar dari Konstitusi Amerika Serikat dengan menyatakan: 'I think that for the prompt, clear and consistent action so necessary in an Executive, unity of person is necessary as with us.'16 Jefferson jujur mengakui bahwa unitary executive pada presiden menurut konstitusi presidensial diilhami oleh sistem monarki. Jeremy D. Bailey memparafrase pemikiran Jefferson sebagai berikut:
The problem was that republican government hitherto lacked the unity of action of a monarchy, but the invention of the president would make republican government at least as effective as a monarchy, since the president "produces unity of action in all the branches of the government." By unifying democratic wills under a single-minded adminis-tration, the presidential system could enjoy one benefit of monarchy. ${ }^{17}$

Mau tidak mau kondisi demikian perlu didemokratiskan karena presiden di sini, meskipun secara ide mengambil manfaat dari sistem monarki, adalah kepala pemerintahan dari pemerintahan republik. Hal ini adalah ciri khas sistem presidensial, di mana berlaku pembatasan berdasarkan asas demokrasi, yang membedakannya dengan sistem monarki yang turun temurun, sehingga:

The will of the nation is the foundation for legitimate government. By submitting to the will of the majority, rather than to the one or the few, government is made "rational" in the sense that the errors of the majority will be more "honest, solitary and shortlived" than the errors of the one or the few. Serving as a "rational and peaceable instrument of reform," elections replace the "sword" as the method by which a nation can "declare" its "will”. 18

Karena lebih memprioritaskan sentralisasi kekuasaan eksekutif pada diri presiden maka kecurigaan bahwa teori unitary executive tidak demokratis, secara sumir tidak sepenuhnya keliru.

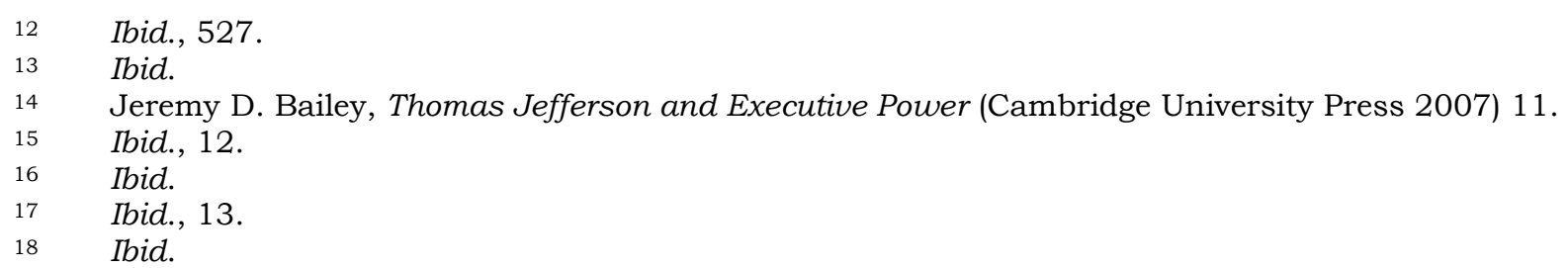


Tetapi jika prinsip itu adalah supremasi konstitusi, unitary executive niscaya adanya. Konstitusi memposisikan presiden sebagai pemegang kekuasaan eksekutif, dan karena itu, sekaligus, presiden adalah Chief Executive satusatunya karena tidak ada kepala eksekutif lain, secara konstitusional, di luar presiden. Dengan demikian, menerapkan pengertian teoretis di atas, poin pengertian yang hendak dipertahankan di sini dalam menginterpretasi Pasal 4 ayat (1) UUD NRI 1945 dengan didikte asas presidensialisme adalah: Presiden Republik Indonesia memegang kekuasaan pemerintahan atau eksekutif sebagai unitary executive dengan implikasi kekuasaan tersebut adalah "the President's sole authority" karena presiden merupakan Chief Executive yang dipilih secara langsung oleh rakyat.

\section{Hubungan Pusat - Daerah yang Abnormal}

Sub-judul ini akan menjelaskan kondisi abnormal dari hubungan pusatdaerah di Indonesia dengan merujuk pada UU yang berlaku. Kondisi tersebut dikualifikasikan abnormal karena tidak sesuai dengan asas presidensialisme. Lebih spesifik lagi, ketidaksesuaian tersebut karena presiden tidak diposisikan sebagai unitary executive dengan kepala daerah dipilih rakyat secara langsung. Selain mengetengahkan kondisi abnormal yang ada, subjudul ini juga akan mengemukakan alasan substantif untuk mengakhirinya dengan mengacu pada pentingnya kekuasaan appointment and removal pada presiden terhadap pejabat-pejabat di lingkungan kekuasaannya.

Hubungan pusat - daerah di Indonesia digariskan secara konstitusional sebagai negara kesatuan yang desentralistik di mana daerah diberikan otonomi yang seluas-luasnya untuk menjalankan urusan pemerintahan yang didesentralisasikan. Secara teori, konsep negara kesatuan memiliki pengertian:

the sovereignty is undivided, or, in other words, that the powers of the central government are unrestricted, for the constitution of a unitary State does not admit of any other law-making body than the central one. If the central power finds it convenient to delegate powers to minor bodies whether they be local authorities or colonial authorities it does so, be it remembered, from the plenitude of its own authority and not because the constitution says it must, or because the various parts of the State have a separate identity which they have to some extent retained on joining the larger body. ${ }^{19}$

Konstruksi yuridis hubungan pusat - daerah yang diletakkan oleh UU No. 23 Tahun 2014 tentang Pemerintahan Daerah (selanjutnya disebut UU No. 23 Tahun 2014) telah koheren dengan konsepsi teoretis negara kesatuan (yang desentralistik). UU No. 23 Tahun 2014 mengkonstruksikan kekuasaan daerah dalam penyelenggaraan urusan pemerintahan sebagai derivasi dari kekuasaan presiden yang merupakan pemegang kekuasaan pemerintahan sesuai Pasal 4 ayat (1) UUD NRI 1945.20 Dengan starting point tersebut dapat disimpulkan bahwa sumber dari kekuasaan daerah adalah kekuasaan pemerintahan presiden yang 
didesentralisasikan (didelegasikan). Oleh karena itu kekuasaan pemerintahan daerah bersifat pelimpahan, tidak bersifat asli (atributif).

Kekuasaan pemerintahan yang dipegang oleh Presiden dijabarkan menjadi berbagai urusan pemerintahan yang diselenggarakan oleh presiden dengan dibantu oleh menteri-menteri dan daerah sesuai dengan asas desentralisasi, dekonsentrasi dan tugas pembantuan. ${ }^{21}$ Atas dasar itu dirumuskan klasifikasi urusan pemerintahan yang meliputi urusan pemerintahan absolut, urusan pemerintahan konkuren dan urusan pemerintahan umum. ${ }^{22}$ Sesuai dengan karakter dari negara kesatuan maka pemerintah pusat menetapkan kebijakan sebagai dasar dalam menyelenggarakan urusan pemerintahan. ${ }^{23}$ Sebagai implikasinya, pemerintah pusat melakukan pembinaan dan pengawasan terhadap penyelenggaraan urusan pemerintahan oleh daerah dan pada analisis akhir presiden bertanggung jawab atas penyelenggaraan urusan pemerintahan oleh pemerintah pusat dan pemerintahan daerah. ${ }^{24}$

Sebagaimana nampak dalam UU No. 23 Tahun 2014, kekuasaan yang didesentralisasikan kepada daerah adalah kekuasaan pemerintahan pada presiden. Itu artinya, presiden adalah sumber kekuasaan bagi kekuasaan pemerintahan yang dimiliki oleh daerah, di mana, pada analisis akhir, dalam menjalankan kekuasaan tersebut daerah diberikan otonomi. Dikaitkan dengan keberlakuan asas presidensialisme (i.c. teori unitary executive), maka isu hukum dalam hubungan pusat - daerah yang akan didiskusikan lebih spesifik adalah pengaturan mekanisme pengisian jabatan kepala daerah yang dipilih rakyat secara langsung.

Berdasarkan pemahaman teoretis yang telah diberikan di atas, pengaturan demikian lebih dekat pada teori plural executive ketimbang unitary executive. Hal ini berimplikasi yuridis "melemahkan" kontrol presiden kepada daerah, khususnya kepala daerah, karena untuk menduduki jabatannya mereka dipilih langsung oleh rakyat sehingga kepala-kepala daerah lebih merasa bertanggung jawab kepada yang memilihnya, ketimbang menjadi "orangnya presiden". 25 Oleh karena itu, pertanyaan spesifiknya: Apakah ranah keberlakuan asas presidensialisme, yang diidealkan menurut teori unitary executive, masih cukup bermakna dalam hubungan pusat - daerah dalam kondisi "desentralisasi demokrasi" di mana rakyat secara langsung memilih kepala daerahnya sendiri?

Argumen saya adalah pemilihan kepala daerah secara langsung merupakan praktik abnormal yang tidak koheren dengan kedudukan presiden sebagai pemegang kekuasaan eksekutif dan sekaligus Chief Executive sesuai konstitusi presidensial. Oleh karenaitu, dari hasil diagnosis yang

\footnotetext{
$21 \quad$ Pasal 5 ayat (2) - (4) UU No. 23 Tahun 2014.

Pasal 9 ayat (1) UU No. 23 Tahun 2014.

Pasal 6 UU No. 23 Tahun 2014.

Pasal 7 UU No. 23 Tahun 2014.

Salah satu isu kontrol oleh presiden berdasarkan teori unitary executive adalah kekuasaan presiden terkait dengan menunjuk dan memberhentikan pejabat-pejabat di lingkungan eksekutif.
} 
dilakukan, fenomena ini adalah masalah jika dikaitkan dengan gagasan keberlakuan asas presidensialisme dalam hubungan pusat - daerah di Indonesia berdasarkan unitary executive. Desentralisasi, dalam kerangka negara kesatuan, tidak mengkondisikan timbulnya negara dalam negara. Dalam negara kesatuan yang desentralistik, asasnya ialah hanya ada satu badan pembentuk UU dan badan yudisial. Oleh karena itu, dengan desentralisasi, yang didesentralisasikan (baca: didelegasikan) hanya urusan pemerintahan (eksekutif) yang berada di tangan presiden (saja!).

Untuk memulai diskusi kita, yang menjadi pra-pemahaman adalah asas konstitusional pengisian jabatan kepala daerah di mana Pasal 18 ayat (4) UUD NRI 1945 menentukan bahwa kepala daerah dipilih secara demokratis. Selanjutnya, untuk implementasinya, dibentuk UU mengenai mekanisme pengisian jabatan kepala daerah. UU yang saat ini berlaku adalah UU No. 1 Tahun 2015 tentang Penetapan Peraturan Pemerintah Pengganti Undang-Undang Nomor 1 Tahun 2014 Tentang Pemilihan Gubernur, Bupati, dan Walikota Menjadi UndangUndang (selanjutnya disebut UU No. 1 Tahun 2015). Pengaturan ini sempat mengalami polemik di mana semula keputusan politiknya adalah pemilihan kepala daerah dilakukan oleh Dewan Perwakilan Rakyat Daerah (DPRD). Menanggapi polemik tersebut Presiden Susilo Bambang Yudhoyono menerbitkan Perppu No. 1 Tahun 2014 yang kemudian disetujui oleh DPR dan disahkan menjadi UU No. 1 Tahun 2015. UU No. 1 Tahun 2015 telah mengalami dua kali perubahan, terakhir dengan UU No. 10 Tahun 2016. Pada poin ini saya tidak menyinggung aspek prosedural dalam pemilihan kepala daerah, tetapi aspek substansialnya, yaitu nihilnya kekekuasaan pada presiden untuk menunjuk, dan memberhentikan, kepala daerah secara unilateral seperti yang berlaku pada menteri-menteri.

Sebagaimana tertulis, pembentuk UU memahami pemilihan kepala daerah secara langsung adalah dalam konteks demokrasi, yaitu pelaksanaan kedaulatan rakyat: 'Pemilihan Gubernur, Bupati, dan Walikota yang selanjutnya disebut Pemilihan adalah pelaksanaan kedaulatan rakyat di provinsi dan kabupaten/kota untuk memilih gubernur, bupati, dan walikota secara langsung dan demokratis.'26 Kebijakan dalam pembentukan UU, yang pada mulanya adalah Perpu, menyatakan:

a. bahwa untuk menjamin pemilihan Gubernur, Bupati, dan Walikota dilaksanakan secara demokratis sebagaimana diamanatkan dalam Pasal 18 ayat (4) UUD NRI 1945 maka kedaulatan rakyat serta demokrasi dari rakyat, oleh rakyat, dan untuk rakyat wajib dihormati sebagai syarat utama pelaksanaan pemilihan gubernur, bupati, dan walikota;

b. bahwa kedaulatan rakyat dan demokrasi sebagaimana dimaksud dalam huruf a, perlu ditegaskan dengan pelaksanaan pemilihan gubernur, bupati, dan walikota 
secara langsung oleh rakyat, dengan tetap melakukan beberapa perbaikan mendasar atas berbagai permasalahan pemilihan langsung yang selama ini telah dijalankan. ${ }^{27}$ Pemahaman di atas jelas tidak koheren dengan pemahaman yang diberikan oleh teori unitary executive di mana keberlakuan kontekstualnya dibangun atas dasar pra-pemahaman keberlakuan asas presidensialisme dalam isu hubungan pusat-daerah. Dalam konteks demikian dapat disimpulkan, antara asas presidensialisme dengan asas demokrasi, pembentuk UU lebih memilih memberikan prioritas untuk keberlakuan asas demokrasi.

Seperti dinyatakan sebelumnya, pemilihan kepala daerah secara langsung oleh rakyat telah mengurangi kekuasaan presiden. Menurut teori unitary executive, presiden harus memiliki kekuasaan untuk menunjuk dan memberhentikan sendiri pejabatpejabat di lingkungan eksekutif. Oleh karena itu, menggunakan parameter ini, prosedur pengisian jabatan kepala daerah lebih dekat dengan teori plural executive dengan maksud di baliknya adalah menghormati kedaulatan rakyat untuk memilih pemimpin bagi daerahnya. Maksud demikian tentu baik. Tetapi hal baik belum tentu benar secara hukum. Dipilih langsung oleh rakyat memang mampu menggambarkan kondisi demokrasi paling ideal; tetapi ditunjuk oleh presiden yang memiliki mandat demokratis bersifat nasional juga tetap demokratis walaupun tidak sedemokratis jika dipilih langsung oleh rakyat. ${ }^{28}$

Kelemahan dari mekanisme pemilihan kepala daerah langsung dikaitkan dengan keberlakuan teori unitary executive adalah kecenderungan loyalitas kepala daerah tidak kepada presiden. Hal ini berimplikasi lebih lanjut pada kemampuan presiden untuk secara eksklusif mengarahkan kepala daerah supaya bertindak sesuai dengan kebijakan presiden, yang pada analisis akhir demi suksesnya program kerja presiden karena atas dasar itulah presiden akan menghadapi penghakiman oleh rakyat pada akhir masa jabatannya. ${ }^{29}$ Secara sederhana dapat disimpulkan, pemilihan kepala daerah oleh rakyat dapat mengganggu konsolidasi tim eksekutif di bawah presiden. Oleh karena itu, mekanisme pengisian jabatan yang bersifat unilateral pada presiden, termasuk kekuasaan presiden atas dasar pertimbangan like or dislike untuk mengganti pejabat di lingkungan kekuasaannya justru memiliki makna sangat strategis dalam konteks sistem presidensial.

Steven G. Calabresi dan Saikrishna B. Prakash menjelaskan pentingnya kekuasaan menunjuk:

Appointments to executive departments determine who will help the President implement his powers and responsibilities. It would make little sense to force the President to deal with officers who fundamentally

$27 \quad$ Menimbang huruf a dan b Perppu No. 1 Tahun 2014.

28 Lihat infra catatan kaki nomor 44

29 Calabresi and Terrell menyebut isu ini sebagai isu akuntabilitas. Steven G. Calabresi and Nicholas Terrell, 'The Fatally Flawed Theory of the Unbundled Executive' (2009) 93 (5) Minnesota Law Review 1696, 1712-1716. 
disagree with his administrative or political philosophy. ${ }^{30}$

Poin pendapat yang dikemukakan Calabresi dan Prakash sangat jelas. Oleh karena itu, dalam konteks Indonesia, yang akan kita lihat adalah apakah kelemahan di bagian hulu (ketiadaan kekuasaan pada presiden untuk menunjuk) juga diikuti kelemahan di bagian hilir (memberhentikan).

Terkait dengan itu maka selanjutnya akan didiskusikan isu peluang pemberhentian kepala daerah oleh presiden. Seperti dijelaskan sebelumnya, dua unit analisis ini, menunjuk dan memberhentikan secara unilateral pejabat-pejabat di lingkungan kekuasaan eksekutif, adalah dua unit analisis paling mendasar dalam menjelaskan apakah presiden sebagai kepala pemerintahan memang beroperasi berdasarkan teori unitary executive ataukah berdasarkan teori plural executive. ${ }^{31}$ Padahal, menurut Steven G. Calabresi dan Kevin $H$. Rhodes, menunjuk dan memberhentikan pejabat-pejabat di ranah kekuasaan eksekutif adalah aplikasi teori unitary executive paling lemah. ${ }^{32}$

Kekuasaan memberhentikan merupakan instrumen untuk "mendisiplinkan" pejabat-pejabat di lingkungan kekuasaan eksekutif supaya mereka menjalankan kekuasaan seperti dikehendaki presiden. Itu artinya, jika presiden mengganti pejabat yang bersangkutan, pemberhentian merupakan bentuk hukuman karena presiden tidak setuju dengan tindakannya. Dengan pengertian lain, kekuasaan ini memberikan kesempatan kepada presiden untuk dapat melakukan konsolidasi atas tim eksekutif di bawah pimpinannya. Hal ini ditegaskan oleh Calabresi dan Prakash sebagai berikut:

The President must also have a removal power so that he will be able to maintain control over the personnel of the executive branch. The President's power over nominations and his exclusively held executive power strongly suggest that he must be able to remove federal officers who he feels are not executing federal law in a manner consistent with his administrative agenda. Inferior executive officers are, after all, the President's men and women, assisting him in the exercise of his constitutional powers. If he decides that they are impeding his administrative program or are simply doing a poor job in providing what Hamilton might have called an "energetic" administration, he must be able to replace them with others. ${ }^{33}$

Dalam kasus Indonesia, presiden sulit untuk memberhentikan kepala daerah karena asasnya adalah kepala daerah "hampir" independen dari jangkauan kekuasaan presiden untuk memberhentikan sebab dipilih langsung oleh rakyat. Kepala-kepala daerah, apakah provinsi atau kabupaten/kota, sulit diposisikan sebagai "orangnya presiden" kecuali mereka dengan sadar memposisikan diri demkian. Hal ini

30 Steven G. Calabresi and Saikrishna B. Prakash, 'The President's Power to Execute the Laws' (1994) 104 (3) Yale Law Journal 541, 598.

31 Cf. Richard J. Pierce Jr., 'Saving the Unitary Executive Theory from Those Who Would Distort and Abuse It: A Review of The Unitary Executive by Steven G. Calabresi and Christopher S. Yoo' (2010) 12 (2) Journal of Constitutional Law 593, 593-613.

32 Steven G. Calabresi and Kevin H. Rhodes, 'The Structural Constitution: Unitary Executive, Plural Judiciary' (1992) 105 (6) Harvard Law Review 1153, 1166.

33 Calabresi, 'The President's Power to Execute the Laws' (n 30) 597. 
adalah kekuatan mereka karena dipilih secara langsung oleh rakyat. ${ }^{34}$ Untuk itu, diskusi isu bagian hilir tentu harus memperhatikan pra-kondisi yuridis, bukan politis, dalam hal ini syaratsyarat hukum untuk kekuasaan itu dapat dijalankan. Hal ini menjelaskan kenapa isu ini tidak mudah.

Walau dipilih secara langsung oleh rakyat, tidak berarti secara yuridis presiden nihil kekuasaan untuk dapat memberhentikan kepala daerah. Hanya kekhususannya, dalam kasus pemberhentian, tindakan presiden harus berdasarkan alasan objektif yang ditentukan oleh UU, tidak oleh pertimbangan like or dislike yang bersifat diskresioner, ${ }^{35}$ termasuk ketentuan proseduralnya. 36 Poin utama sebagai catatan di sini adalah tidak ada alasan pemberhentian yang bersifat presidensial.

Dalam konteks demikian presiden masih agak diuntungkan oleh kondisi UU, meski agak minimalis, yang mengikat kepala daerah dengan sejumlah syarat sebagai bentuk kendali atas keotonomiannya supaya tidak "sewenang-wenang" kepada presiden. Untuk membuka ruang kontrol presiden terhadap kepala daerah, UU memberlakukan kewajiban kepada kepala daerah dan wakil kepala daerah yang meliputi: a. memegang teguh dan mengamalkan Pancasila, melaksanakan UUD NRI 1945 serta mempertahankan dan memelihara keutuhan Negara Kesatuan Republik Indonesia;

b. menaati seluruh ketentuan peraturan perundang-undangan;

c. mengembangkan kehidupan demokrasi;

d. menjaga etika dan norma dalam pelaksanaan urusan pemerintahan yang menjadi kewenangan daerah;

e. menerapkan prinsip tata pemerintahan yang bersih dan baik;

f. melaksanakan program strategis nasional; dan

g. menjalin hubungan kerja dengan seluruh instansi vertikal di daerah dan semua perangkat daerah. ${ }^{37}$

Hal yang sangat penting terkait dengan keberhasilan kebijakan presiden dalam hubungan dengan kepala daerah adalah kewajiban kepala daerah (dan wakil kepala daerah) untuk melaksanakan program strategis nasional. Ketentuan ini dapat menjadi pintu masuk untuk presiden melakukan kontrol terhadap kepala daerah (dan wakil kepala daerah) karena kepala daerah (dan wakil kepala daerah) yang tidak melaksanakan program strategis nasional dapat dikenakan sanksi

34 Jika menurut Linz kelemahan sistem presidensial adalah potensi timbulnya saling ketegangan antara legislatif - eksekutif akibat dual democratic legitimacy (keduanya sama-sama berhak mewakili kehendak rakyat karena sama-sama dipilih rakyat). Juan Linz, 'The Perils of Presidentialism' (1990) 1 (1) Journal of Democracy 51, 62-64. Mutatis mutandis isu demikian juga terjadi dalam hubungan antara pusat - daerah di Indonesia saat ini. Ironisnya, dual democratic legitimacy justru terjadi secara internal di ranah kekuasaan eksekutif antara presiden dengan kepala daerah karena kepala daerah dipilih secara langsung oleh rakyat. Pasal 78 UU No. 23 Tahun 2014.

Pasal 80 dan 81 UU No. 23 Tahun 2014.

Pasal 67 UU No. 23 Tahun 2014. 
administratif berupa teguran tertulis. ${ }^{38}$ Dalam hal teguran tertulis telah disampaikan 2 (dua) kali berturut-turut dan tetap tidak dilaksanakan, kepala daerah dan/atau wakil kepala daerah diberhentikan sementara selama 3 (tiga) bulan. ${ }^{39}$ Sanksi lebih tegas diberikan jika kepala daerah dan/atau wakil kepala daerah telah selesai menjalani pemberhentian sementara, tetap tidak melaksanakan program strategis nasional, maka yang bersangkutan diberhentikan sebagai kepala daerah dan/atau wakil kepala daerah. ${ }^{40}$ Itu artinya, penugasan oleh presiden, sepanjang penugasan tersebut termasuk program strategis nasional, memberikan kekuasaan kontrol cukup besar bagi presiden kepada kepala daerah.

\section{Penerapan Teori Unitary Executive dalam Hubungan Pusat - Daerah}

Sub-judul ini, sebagai preskripsi, akan mendiskusikan proposal untuk normalisasi hubungan pusat - daerah di Indonesia sesuai asas presidensialisme. Atas dasar itu, dikaitkan dengan tuntutan kompatibilitas terhadap asas presidensialisme, hubungan pusat daerah seyogianya ditata kembali berdasarkan teori unitary executive, khususnya pengaturan tentang pengisian jabatan kepala daerah. Proposal tersebut didasari oleh logika bahwa ranah kekuasaan daerah adalah kekuasaan pemerintahan atau eksekutif dan kekuasaan tersebut bukan kekuasaan asli tetapi kekuasaan derivatif, melalui desentralisasi, dari kekuasaan pemerintahan yang dipegang oleh presiden. Oleh karena itu kepala daerah harus berada di bawah kontrol presiden, dan bentuk kontrolnya adalah prosedur pengisian jabatan di mana presiden dapat menunjuk dan memberhentikan kepala daerah secara unilateral. Proposal ini dibatasi hanya untuk pengisian jabatan kepala daerah provinsi, dan tidak termasuk pengisian jabatan kepala daerah kabupaten/kota. Hal itu sekaligus akan diberikan rasionalisasi.

Isu utama kita sejak reformasi adalah kecurigaan sangat besar terhadap kekuasaan presiden. Salah satu bentuk respons atas kecurigaan tersebut adalah dengan mendowngrade kekuasaan presiden melalui perubahan UUD NRI 1945. Adapun isu yang menjadi perhatian di sini adalah pembatasan terhadap kekuasaan pemerintahan yang dipegang oleh presiden. Pembatasan tersebut juga dilakukan melalui UUD. Adapun poin utama kritik saya adalah diabaikannya karakter konstitusi kita sebagai konstitusi presidensial dalam proses pembatasan tersebut, termasuk dalam hubungan pusat - daerah. Untuk itu, sebelum memberikan rekomendasi institusional dalam penataan hubungan pusat - daerah berdasarkan asas presidensialisme, saya akan menjelaskan terlebih dulu konstruksi logis keberlakuan asas presidensialisme terhadap isu hubungan pusat - daerah.

Sesuai dengan asas UUD NRI 1945, sistem pemerintahan kita adalah sistem presidensial. Oleh karena itu, Pasal 68 ayat (2) UU No. 23 Tahun 2014. Pasal 68 ayat (3) UU No. 23 Tahun 2014. 
asas presidensialisme adalah preskripsi dalam mendiskusikan isu tentang kekuasaan presiden di Indonesia yang mencakup ranah kekuasaan pemerintahan atau eksekutif. Dengan demikian, menjawab isu tentang hubungan pusatdaerah di Indonesia, asas presidensialisme sangat relevan karena kekuasaan yang didelegasikan kepada daerah adalah kekuasaan pemerintahan yang dipegang oleh presiden berdasarkan Pasal 4 ayat (1) UUD NRI 1945. Kondisi berbeda jika asasnya adalah federalisme. Dalam negara federal, daerah memiliki kekuasaan asli (kekuasaan atributif) yang dijamin dalam konstitusi, bukan kekuasaan yang sifatnya pelimpahan. ${ }^{41}$ Oleh karena itu, mendiskusikan keberlakuan asas presidensialisme dalam hubungan antara pemerintah federal - negara bagian tidak relevan karena negara bagian memiliki kekuasaan asli, bukan hasil pelimpahan kekuasaan pemerintahan dari presiden.

Poin saya dengan keberlakuan asas presidensialisme dalam isu hubungan pusat-daerah adalah memposisikan presiden sebagai unitary executive dengan implikasi pengawasan oleh presiden kepada daerah berbentuk: 'Presidential removal power, power to gather information from subordinate executive officials, and power to bind subordinate executive officials.' Posisi demikian, sesuai penjelasan di atas, dapat dijustifikasi secara logis berdasarkan prinsip inferensial sederhana dengan mengacu pada proposisiproposisi sebagai berikut. Pertama, Indonesia adalah negara kesatuan, sehingga kekuasaan yang dimiliki daerah bukan kekuasaan atributif, tetapi delegatif. Kedua, sistem pemerintahan Indonesia adalah presidensial di mana presiden adalah pemegang kekuasaan pemerintahan sekaligus Chief Executivetunggal. Ketiga, daerah hanya memiliki kekuasaan pemerintahan (tidak memiliki kekuasaan legislatif dan yudisial) yang berasal dari delegasi kekuasaan pemerintahan yang dipegang oleh presiden. Keempat, presiden bertanggung jawab atas penyelenggaraan semua urusan pemerintahan (baik pusat maupun daerah). Koheren dengan keempat proposisi tersebut maka asas presidensialisme "seharusnya" berlaku sebagai preskripsi bagi isu hubungan pusat - daerah di Indonesia, termasuk konsepsi presiden sebagai unitary executive. Sebagai implikasinya, dalam hubungan pusat - daerah, "seharusnya" berlaku kekuasaan presiden sebagai unitary executive, dengan ranah: 'Presidential removal power, power to gather information from subordinate executive officials, and power to bind subordinate executive officials.'

Seperti telah dijelaskan, isu dalam hubungan pusat - daerah dikaitkan dengan asas presidensialisme adalah prosedur pengisian jabatan kepala daerah yang lebih mengarah pada teori plural executive ketimbang unitary executive. Sesuai teori unitary executive dalam menunjang keberlakuan asas presidensialisme, mekanisme pengisian jabatan di lingkungan kekuasaan pemerintahan seyogianya dipercayakan kepada presiden secara unilateral karena presiden adalah kepala pemerintahan atau Chief Executive. Memang, gagasan pembatasan sangat 
penting. Tetapi, pembatasan kekuasaan presiden tetap harus memperhatikan hakikat dari kekuasaan presiden sehingga pembatasannya dilakukan dalam koridor hukum yang wajar. Pembatasan dengan jalan menghilangkan kekuasaan presiden untuk menunjuk dan memberhentikan pejabat-pejabat di lingkungan kekuasaan pemerintahan merupakan gagasan yang tidak rasional karena kekuasaan tersebut justru diperlukan oleh presiden supaya dapat mengontrol lingkungan kekuasaan pemerintahan secara efektif seperti dikehendaki oleh teori unitary executive.

UUD NRI 1945 memberikan preskripsi supaya kepala daerah dipilih secara demokratis. UU yang mengimplementasikan asas konstitusional ini memilih pendekatan pengaturan bahwa kepala daerah dipilih oleh rakyat secara langsung. Dalam kaitan dengan teori unitary executive, sudah didiskusikan sebelumnya, pengaturan demikian tidak koheren dengan pemahaman bahwa presiden sebagai kepala pemerintahan seharusnya memegang kontrol penuh atas pejabat-pejabat di lingkungan kekuasaannya. Dengan kepala daerah dipilih oleh rakyat secara langsung maka implikasinya adalah terjadi persaingan legitimasi antara presiden dengan kepala daerah.

Jabatan kepala daerah, seolaholah kepribadian lain dari presiden, walaupun pada hierarki yang lebih rendah. Dengan kondisi hukum yang demikian, para kepala daerah, sepanjang menyangkut mekanisme pengisian jabatan, menjadi independen posisinya dari presiden. Prestise semacam ini meningkatkan pamor para kepala daerah; tetapi menciptakan "bencana" bagi presiden (terutama jika kepala daerah terpilih adalah "lawan politiknya"). Kemampuan presiden untuk melakukan kontrol secara efektif kepada kepala daerah agak berkurang karena, kecenderungan politisnya, kepala daerah tidak merasa bahwa presiden adalah "bos-nya". Padahal untuk keberhasilan kebijakan-kebijakannya, peranan para kepala daerah juga sangat penting karena tidak mungkin semua dikerjakan sendiri oleh presiden.

Poin utama pendapat hukum saya adalah, di bawah dikte konstitusi presidensial, perlunya kontrol presiden secara efektif dilembagakan dalam pengaturan hubungan pusat-daerah; bukan sebaliknya, demokratisasi yang meminimalisir kontrol presiden secara efektif dalam pengaturan hubungan pusat-daerah, khususnya dalam hubungan dengan kepala daerah. Dengan keberlakuan asas presidensialisme maka implikasinya adalah presiden perlu diberikan insentif institusional sebagai respons atas dampak negatif dari desentralisasi demokrasi yang mengurangi kekuasaannya dalam hubungan pusat daerah, dalam hal ini menunjuk kepala daerah secara unilateral karena kepala daerah tersebut secara fungsi berada di ranah kekuasaan presiden sebagai kekuasaan pemerintahan. Pertanyaannya: Apakah solusi yuridis untuk mengatasi kondisi existing law yang arahnya adalah praktik plural executive?

Dua solusi yuridis saya usulkan sebagai preskripsi untuk isu di atas. Pertama, daerah provinsi tidak lagi diposisikan sebagai daerah otonom, 
sehingga gubernur ditunjuk oleh presiden dan diposisikan sebagai "orang presiden" dalam koridor dekonsentrasi. ${ }^{42}$ Kedua, memperkuat posisi kebijakan presiden di mana kepala daerah, ketika proses pemilihan kepala daerah, dilarang menjanjikan sesuatu yang tidak sejalan dengan kebijakan pemerintah atau presiden. Poin kedua ini sebenarnya sudah nampak dalam UU No. 23 Tahun 2014, tetapi baik presiden sendiri, maupun kepala daerah, cenderung lebih mengutamakan pendekatan politik ketimbang hukum. Presiden sulit untuk tegas kepada kepala daerah, dan sebaliknya, kepala daerah mengkapitalisasi kondisi ini sebagai modal elektoral.

Kembali pada solusi yuridis yang hendak saya usulkan. Alasan untuk kepala daerah provinsi ditunjuk oleh presiden adalah jalan tengah penerapan teori unitary executive. Sebagai jalan tengah, itu artinya yang dikondisikan untuk pemilihan kepala daerah secara langsung hanya kepala daerah kabupaten/kota. Solusi ini tidak contradictio in terminis dengan asas demokrasi karena pertimbangan beberapa hal. Pertama, ranah kekuasaan yang dijalankan kepala daerah adalah ranah kekuasaan yang dipegang oleh presiden. Oleh karena itu sudah selayaknya jika, setidaknya, kepala daerah provinsi ditunjuk oleh presiden. Kedua, pra-kondisi demokrasi. Pertama-tama, dalam sistem presidensial, konsep demokrasi tersebut perlu kita pahami secara kontekstual.
Demokrasi dalam sistem presidensial adalah dimungkinkannya rakyat untuk memilih sendiri kepala pemerintahannya, yaitu presiden. Sementara secara hakikat, sistem presidensial sendiri agak kurang demokratis jika demokrasi yang dimaksudkan adalah partisipasi seluas-luasnya bagi rakyat dalam pemerintahan. Presiden, dalam sistem presidensial, sama seperti raja; bedanya sebatas presiden itu dipilih, sementara raja itu turun temurun.

Dengan latar belakang di atas maka perspektif demokrasi dari kekuasaan presiden untuk menunjuk kepala daerah provinsi perlu kita pahami berbeda. Demokrasi dalam mekanisme ini adalah demokrasi perwakilan dalam pengertian presiden adalah institusi tunggal paling representatif secara demokratis. Oleh karena itu, kekuasaan presiden untuk menunjuk kepala daerah provinsi, menurut hemat saya, tetap demokratis dalam kadar tertentu. Level paling tinggi tentu ketika rakyat sendiri yang diberikan hak untuk memilih sendiri kepala daerahnya. Sementara demokrasi dalam pengertian ini adalah rakyat telah mewakilkan haknya untuk memilih sendiri kepala daerahnya kepada presiden yang dipilihnya. Pengertian demikian adalah penjelasan paling maksimal untuk menjustifikasi perspektif demokrasi dalam kekuasaan presiden untuk menunjuk kepala daerah provinsi, yang tentunya, secara substantif, perspektif demokrasi yang ditawarkan adalah demokrasi yang

42 Pendapat ini bukan isu baru karena sudah menjadi perdebatan klasik terkait dengan titik berat otonomi akan diletakkan di mana. Bagi saya, dengan mengajukan poin rekomendasi demikian, saya lebih memilih titik berat otonomi pada kabupaten atau kota. Sementara provinsi hanya bersifat administratif sebagai kepanjangan tangan presiden. 
minimalis. Demokrasi yang sebenarnya, yang saya akui sulit untuk dinegasikan, ada pada jenjang daerah kabupaten atau kota. Menegasikannya sama artinya dengan berusaha memutar balik arah jarum jam. Oleh karena itu dapat disimpulkan bahwa teori unitary executive yang saya usulkan adalah teori "setengah hati".

Asas presidensialisme menjadikan hubungan pusat - daerah kurang demokratis adalah benar adanya. Demokratis yang saya maksudkan di sini adalah keleluasaan daerah dalam menjalankan pemerintahan sendiri, self-government, dalam dua pengertian: Mampu memutuskan sendiri pemimpinnya dan mampu memutuskan sendiri peraturan yang berlaku bagi dirinya. ${ }^{43}$ Dua pengertian tersebut, dengan berlakunya asas presidensialisme dalam hubungan pusatdaerah, seharusnya tidak dapat diterapkan pada tingkatan yang maksimal. Oleh karena itu, saya memahaminya, hubungan pusatdaerah menjadi agak kurang demokratis ketika sebagai pra-kondisi diberlakukan asas presidensialisme.

Ideal demokrasi dideskripsikan secara otoritatif oleh Art. 21 (3) the Universal Declaration of Human Rights sebagai berikut: 'The will of the people shall be the basis of the authority of government.' Pertanyaan kritis yang timbul dari pernyataan itu adalah: Apakah, dalam konteks asas negara kesatuan dan asas presidensialisme, legitimasi demokratis pemerintah tidak cukup terletak pada presiden saja, sebagai representasi pemimpin pemerintahan nasional yang basis konstituennya juga bersifat nasional? ${ }^{44}$ Jika asas presidensialisme disepakati sudah mengandung elemen demokrasi di dalamnya dengan presiden memerintah melalui mekanisme pemilihan oleh rakyat secara langsung maka alangkah naifnya kita berpikiran bahwa kepala daerah harus dipilih secara langsung oleh rakyat, supaya demokratis, dan tidak boleh ditunjuk oleh presiden.

Apabila kita percaya bahwa presiden, yang untuk berhasil menghadapi "penghakiman" rakyat dalam pemilu selanjutnya harus sukses menjalankan program-programnya supaya dapat terpilih kembali, juga adalah wakil rakyat yang terpilih melalui mekanisme demokratis, sudah seharusnya pula jika presiden kita percaya untuk menentukan sendiri, dalam tataran paling luas, orangorangnya. Dalam konteks logika elektoral saya percaya bahwa presiden seharusnya akan bertindak bijak (walau inferensi faktual ini tidak boleh dipercaya begitu saja). Saya melihat, situasi demikian justru akan

43 Attracta Ingram, A Political Theory of Rights (Oxford University Press 1994) 108; Christopher L. Eisgruber, Constitutional Self-Government (Harvard University Press 2001) 85; Friedrich A. von Hayek, The Constitution of Liberty (2nd ed, The University of Chicago Press 2011) 61.

44 Pertanyaan ini diilhami oleh pernyataan historis Woodrow Wilson yang berpendapat: "[t]here is no national party choice except that of President. No one else represents the people as a whole, exercising a national choice; ... [The President] is the representative of no constituency, but of the whole people." Seperti dikutip dalam Jide Nzelibe, 'Does the Unitary Presidency Really Need a Nationalist Justification?' (2010) 12 (2) Journal of Constitutional Law 623, 625. Menurut hemat saya, pernyataan Wilson sangat menarik, walaupun Nzelibe mengkritiknya sebagai terlalu berlebihan jika dilihat secara empiris. 
mendorong akuntabilitas penuh presiden seperti dinyatakan oleh Alexander Hamilton: 'Decision, activity, secrecy, and dispatch will generally characterize the proceedings of one man in a much more eminent degree than the proceedings of any greater number.'45 Jika pun pada akhirnya terjadi kesalahan, maka lebih mudah menyalahkan yang satu orang ketimbang menyalahkan banyak orang atas keputusan yang diambil (walaupun ada pula rasa aman jika kesalahan dalam keputusan terjadi karena keputusan itu diambil oleh banyak orang).

Poin utama dari diskusi kita adalah isu mengenai pengelolaan kekuasaan di ranah kekuasaan pemerintahan yang dipegang oleh presiden. Kondisi yang ada menunjukkan "longgarnya" pengelolaan kekuasaan pemerintahan di ranah hubungan pusat - daerah padahal kekuasaan yang didesentralisasikan kepada daerah adalah kekuasaan pemerintahan yang dipegang presiden. Dampak negatif dari demokratisasi politik pasca reformasi 1998 menurut hemat saya perlu dipikirkan ulang, terutama terkait dengan posisi presiden sebagai pemegang kekuasaan pemerintahan dalam menjalankan kekuasaannya itu di mana sistem konstitusional kita menempuh mekanisme desentralisasi, bukan sentralisasi. Desentralisasi di sini dipahami sebagai pembatasan kekuasaan presiden secara konstitusional pada satu sisi. Tetapi pada sisi lain desentralisasi tersebut tidak boleh dimaknai sebagai upaya untuk memangkas kekuasaan presiden sebagai kepala pemerintahan dalam mengendalikan isu hubungan pusatdaerah.

Dengan latar belakang kontekstual ini rekomendasi terkait dengan keberlakuan asas presidensialisme dalam isu hubungan pusat-daerah didiskusikan. Rekomendasi saya dengan memberikan prioritas kepada asas presidensialisme jelas akan berdampak pada relaksasi demokratisasi. Tetapi dalam posisi demikian saya tidak ingin disebut memberikan rekomendasi yang bersifat anti-demokrasi.

\section{PENUTUP}

Presiden dalam sistem presidensial seyogianya memiliki kemampuan untuk melakukan kontrol penuh dan eksklusif atas semua badan-badan dan pejabatpejabat pemerintah yang memegang dan menjalankan kekuasaan pemerintahan atau eksekutif. Oleh karena itu, jika aspirasi ini yang diinginkan, unitary executive adalah pilihan yang pas untuk penegasan sistem presidensial guna dituangkan ke dalam konstitusi, UUD, atau ke dalam UU.

Preskripsi yang sama berlaku untuk isu hubungan pusat - daerah. Dalam negara kesatuan yang desentralistik, kekuasaan yang dimiliki daerah dalam menyelenggarakan urusan pemerintahan adalah kekuasaan yang bersifat derivatif, dalam hal ini diderivasikan dari kekuasaan eksekutif atau pemerintahan yang dimiliki oleh presiden melalui desentralisasi. Dengan demikian, sudah sewajarnya pula jika

45 Alexander Hamilton, James Madison and John Jay, The Federalist with Letters of "Brutus" (Terence Ball ed, Cambridge University Press 2003) 342. 
presiden diberikan kekuasaan appointment and removal kepala daerah, setidaknya dibatasi untuk kepala daerah provinsi, dengan menjadikan provinsi tidak lagi sebagai daerah otonom.

\section{DAFTAR BACAAN}

\section{Buku}

Bailey JD, Thomas Jefferson and Executive Power (Cambridge University Press 2007).

Eisgruber CL, Constitutional SelfGovernment (Harvard University Press 2001).

Hamilton A, Madison $\mathrm{J}$ and Jay J, (Terence Ball, ed.) The Federalist with Letters of "Brutus" (Cambridge University Press 2003).

Hayek FAV, The Constitution of Liberty ( $2^{\text {nd }}$ ed, The University of Chicago Press 2011).

Ingram A, A Political Theory of Rights (Oxford University Press 1994).

Mezey ML, Presidentialism: Power in Comparative Perspective (Lynne Rienner Publishers 2013).

Strong CF, A History of Modern Political Constitutions (G.P. Putnam's Sons 1963).

\section{Artikel Jurnal}

Calabresi SG and Rhodes KH, "The Structural Constitution: Unitary Executive, Plural Judiciary' (1992) 105 (6) Harvard Law Review. and Prakash SB, The President's Power to Execute the Laws' (1994) 104 (3) Yale Law Journal. and Yoo CS, 'The Unitary

Executive During the First-Half Century' (1997) 47 (4) Case Western Reserve Law Review.

Unitary Executive During the Second-Half Century' (2003) 26 (3) Harvard Journal of Law and Public Policy.

and Terrell N, 'The Fatally Flawed Theory of the Unbundled Executive' (2009) 93 (5) Minnesota Law Review.

Jr Pierce RJ, 'Saving the Unitary Executive Theory from Those Who Would Distort and Abuse It: A Review of The Unitary Executive by Steven G. Calabresi and Christopher S. Yoo' (2010) 12 (2) Journal of Constitutional Law.

Juan L, 'The Perils of Presidentialism' (1990) 1 (1) Journal of Democracy.

Krent HJ, 'From a Unitary Executive to a Unilateral Presidency' (2008) 88 (2) Boston University Law Review.

Lessig L and SunsteinCass R, 'The President and the Administration' (1994) 94 (1) Columbia Law Review.

Miller GP, 'Independent Agencies' (1986) (1) The Supreme Court Review.

Nzelibe J, 'Does the Unitary Presidency Really Need a Nationalist Justification?' (2010) 12 Journal of Constitutional Law.

Prakash SB, 'Hail to the Chief Administrator: The Framers and the President's Administrative Powers' (1993) 102 (4) Yale Law Journal. 
Yoo CS, Calabresi SG, and Nee LD, The Unitary Executive During the Third-Half Century, 1889-1945' (2004) 80 (1) Notre Dame Law Review.

Colangelo AJ, 'The Unitary Executive in the Modern Era, 1945-2004' (2005) 90 (2) Iowa Law Review.

\section{Website}

Fauzan HA, 'Beda Pandangan Anies dengan Jokowi dan Basuki soal Penyebab Banjir' (Tirto, 3 Januari 2020) <https://tirto.id/bedapandangan-anies-dengan-jokowidan-basuki-soal-penyebab-banjireqnp> diakses 21 Januari 2020.

Setiawan R, 'Polemik Abadi Anies dan Jokowi: Naturalisasi vs Normalisasi Sungai' (Tirto, 10 Januari 2020) <https://tirto.id/ polemik-abadi-anies-jokowi-natu ralisasi-vs-normalisasi-sungai-er Bs> diakses 21 Januari 2020.

\section{Peraturan Perundang-Undangan}

The Constitution of The United States.

Undang-Undang Nomor 23 Tahun 2014 tentang Pemerintahan Daerah.

Undang-Undang Nomor 1 Tahun 2015 tentang Penetapan Peraturan Pemerintah Pengganti UndangUndang Nomor 1 Tahun 2014 Tentang Pemilihan Gubernur, Bupati, dan Walikota Menjadi Undang-Undang. 
